\title{
Analysis of e-Government Services: A Study of the Adoption of Electronic Tax Filing in Indonesia
}

\author{
Rosdiana Sijabat \\ Department of Business Administration, \\ Atma Jaya Catholic University of Indonesia \\ (email: rosdiana.sijabat@atmajaya.ac.id)
}

\begin{abstract}
This study explores the impact of perceived usefulness, perceived ease-of-use, and perceived risks of using electronic tax filing (e-Filing) on the intention to use e-Filing through a technology acceptance model framework. The theoretical foundation used in this study is the technology acceptance model (TAM) on 201 valid questionnaires completed by Indonesian taxpayers. The data collected was analyzed by structural equation modelling using SmartPLS (3.0 Version). The results of the study revealed that e-Filing's perceived usefulness and risk were significantly associated with intention to use, while perceived ease-of-use did not have a significant effect. Although the influence of perceived risks significantly mediated the influence of perceived usefulness, it did not significantly mediate the influence of ease-of-use. Gender was found to significantly moderate the influence of e-Filing's perceived usefulness, but not to moderate the influence of perceived ease-of-use. Importance-Performance Matrix Analysis (IPMA) finds that the intention to use e-Filing is most strongly influenced by its perceived usefulness and perceived risk. This implies that policymakers must highlight the perceived usefulness and communicate the perceived risks of e-Filing to ensure taxpayers are willing to use the system. To the best of the author's knowledge, this study is the first to examine both mediation and moderation to analyze the adoption of technology in Indonesia's taxation system and offer a policy perspective through IPMA.
\end{abstract}

\section{Keywords:}

Technology Acceptance Model; e-Filing; usefulness; ease-of-use; risk; IPMA

\section{Introduction}

The rapid rise of e-government has stemmed from advances in information technology, which has promoted increased digital connectivity in organizational, public, and private life (Rana et al., 2017; Zahid \& Din, 2019). One implementation of e-government is electronic-tax filing (hereafter, e-Filing), the filing of annual tax returns through electronic devices. In many countries, particularly developed ones, e-Filing has been systematically implemented to improve tax reporting (Schaupp, Carter \& McBride, 2010). According to the World Bank and
PricewaterhouseCoopers report titled "Paying Taxes 2017", in recent years global tax systems have been transformed as online means of filing have been introduced and expanded (PWC, 2018). One country where e-Filing has been introduced is Indonesia, pursuant to Regulation of the Director General of Taxation No. PER06/PJ./2014. In this article, e-Filing is defined as a means of electronically filing tax returns (known in Indonesia as Surat Pemberitahuan Pajak, or SPT) in real time through the website of Indonesia's Directorate General of Taxation. Since its introduction in 2014, Indonesia's e-Filing system has found wide adoption, with 
the number of users exceeding expectations. In 2015 , for example, the Indonesian government expected 7 million taxpayers to use the e-Filing system; the actual figure was 7.96 million, approximately $12 \%$ higher than expected. This electronic filing medium has been supported through other initiatives. In early 2019, the government issued Regulation of the Director General of Taxation numbered PER-02/PJ/2019 regarding the Means of Filing, Receiving, and Storing Tax Returns. This regulation, building upon Regulation of the Minister of Finance numbered 9/PMK.03/2018, provided new framework for the electronic filing of tax returns.

This study analyses the influence of perceived benefit on intention to use e-Filing systems, as mediated by perceived risk and moderated by gender. This study employs TAM, viewing perceived benefit and ease of use as fundamentally influencing individuals' willingness to adopt technology (Davis, 1989; Venkatesh, et al., 2003; Davis, Bagozzi, \& Warshaw, 1989; Camilleri, 2018). Many studies of technology adoption in Indonesia have used a TAM framework; however, few have investigated e-Filing since it was first implemented in 2014. When this survey was conducted, only a few studies had considered e-Filing adoption in Indonesia, including Widiyanesti and Reynaldi (2017) as well as Pantow, Sutrisno, and Saraswati (2016); both studies simply identified the perceived benefits and ease of use of e-Filing. Studies have also used TAM to investigate e-Filing adoption internationally (Zaidi, Henderson \& Gupta, 2017; Jankeeparsad, Jankeeparsad \& Nienaber, 2015; Kumar \& Gupta, 2017). However, such studies have generally focused on the perceived benefits and ease of use of e-Filing. To fill this gap, this study seeks to produce a more comprehensive understanding of e-Filing adoption. Risk factors have a statistically significant contribution to willingness to adopt e-Filing services (Charag, Fazili \& Bashir,
2019; Mortimer et al., 2016; Bhuasiri et al., 2016). As such, perceived risk is an exogenous factor contributing to taxpayers' decision to use e-filinge-Filing. Gender, likewise, has been found to influence technology adoption (Tanellari et al., 2014; Leon, 2018). However, previous studies have yet to consider how gender influences how taxpayers perceive the benefits and ease-of-use of e-Filing. Gender is thus considered a moderating factor in this study, which contributes a more comprehensive understanding of taxpayers' willingness to adopt e-Filing by incorporating perceived risk and gender into TAM. This study will thus contribute a new scientific understanding of the TAM framework.

According to TAM's framework, individuals' use of technology-including e-Filing - is influenced by their perceptions of its benefits, ease-of-use, and risks. This study will answer the following questions: (1) How do the perceived usefulness, ease-ofuse, and risks of e-Filing influence intention to use among Indonesian taxpayers?; (2) Does the influence of perceived risks mediate the influence of perceived usefulness and easeof-use among Indonesian taxpayers?; (3) Does gender moderate the influence of perceived usefulness, ease-of-use, and risk on intention to use e-Filing? Although many studies have discussed gender and technology, no study has been found that explored the gendered adoption of technology-based services (such as e-Filing) in Indonesia. As such, this study considers the contribution of gender to users' perceptions of usefulness, ease-of-use, and risks in its analysis of taxpayers' intention to use e-Filing. It is hoped that, by analyzing the influence of gender on taxpayers' intention to use e-Filing, this study can recommend a strategy or approach that can help the Indonesian government to formulate targeted, gender-sensitive policies and improve online tax reporting among both male and female taxpayers. 


\section{Literature Review}

Technology Acceptance Model and Intention to Use e-Filing

This study applies TAM's framework to understand individuals' perceptions of information technology (Davis, 1989). TAM considers the psychological conditions in which individuals adopt specific technologies, and as such may be used to predict individuals' decision to adopt new technologies and systems (Bélanger \& Carter, 2012). According to Davis (1989), two factors influence individuals' decisions to adopt new technologies and systems, namely (1) individuals are willing to use new technologies and systems when they perceive it as beneficial, and (2) individuals are willing to use new technologies and systems when they perceive it as easy to use.

\section{Perceived Usefulness of e-Filing}

Individuals are driven to adoptinformation and technology-based services according to their perceptions of said services' usefulness (Anouze \& Alamro, 2019). Frequently, the technologies and systems adopted are those that are seen as improving performance (Hubert et al., 2019). Technology is considered highly beneficial if it has a strong positive correlation with individual performance (Humbani \& Wiese, 2019), including individuals' ability to work and present information (Camilleri, 2018). The higher the value attributed to a technology and system, the greater the desire to adopt it; conversely, the lower the value attributed to a technology and system, the lower the desire to adopt it (Bélanger \& Alamro, 2019). Individuals will be willing to adopt a technology if they believe that said technology will help them do their everyday activities more easily and more effectively (Davis, Bagozzi, \& Warshaw, 1989).

The adoption of e-Filing in Indonesia has also been influenced by users' perceptions of its usefulness. If e-Filing is believed to improve productivity, then individuals will be more motivated to use it and to invite others to use it. However, if individuals believe that e-Filing cannot facilitate their tax reporting, they will be less likely to adopt e-Filing (Zaidi, Henderson \& Gupta, 2017). Individuals tend to perceive e-Filing as more efficient, and thus are willing to adopt it. There is thus a positive association between the perceived benefits of e-Filing and its adoption (Widiyanesti \& Reynaldi, 2017; Pantow, Sutrisno \& Saraswati, 2016). In the light of the above, it can be hypothesized that: H1: Perceived usefulness has a positive and significant impact on taxpayers' intention to use e-Filing.

\section{Perceived Ease of Use of e-Filing}

Perceived ease-of-use refers to the individuals' belief that they will not experience any difficulties or obstacles when using new technologies or systems (Hubert et al., 2019). In other words, new technologies and systems must be easily understood and operated (Hubert et al., 2019). According to Jahongir and Shin (2014), technology and information-based services may be deemed easy to use when it is flexible, readily learned, and easily understood, thereby enabling it to be widely adopted. Technology may be identified as easy to use if its adopters can use it effectively with minimal mental and physical effort (Singh \& Srivastava, 2018). Individuals tend to prefer simpler technologies; as such, simpler technologies are more likely to be adopted than complicated ones (Hubert et al., 2019). Information and technology-based services are deemed easy to use when they are: (1) easily understood and (2) offer easy access to necessary information (Camilleri, 2018). Ease-of-use is also evident in the efficiency of the technology, particularly the limited amount of resources (such as time) necessary to use it to achieve a certain goal (Humbani \& Wiese, 2019).

As such, when a technology is perceived as easy to use, individuals are more likely to adopt it (Leon, 2018; Cho, 2016). This is also true for e-government services such as e-Filing, 
where ease-of-use is a strong indicator of users' willingness to adopt technology and use it for its intended purposes (i.e. for filing tax returns) (see Zaidi, Henderson \& Gupta, 2017). On this basis, it is hypothesized:

H2: Perceived ease of use has a positive and significant impact on taxpayers' intention to use e-Filing.

\section{Perceived Risk of e-Filing}

The decision to adopt technology is also negatively influenced by its perceived risks (Charag, Fazili \& Bashir, 2019). Dinu (2012) defines risk as an element of uncertainty, as the potential to cause irrevocable damage. Perceived risk refers to the potential for an individual to experience harm as a result of using technology or undertaking a specific action. Risk factors are prominent in online activities (Mortimer et al., 2016), as individuals have their own subjective expectations of what will happen after the make their decisions (Charag, Fazili \& Bashir, 2019). If they believe that using online services carries a high level of risk, they will be less willing to use online services and be hesitant to entrust their data to said services. In other words, individuals will be hesitant to use online services if they believe that their data are unsecure (Bhuasiri et al., 2016).

Individuals believe that e-Filing has certain risks that are not found in conventional paper-based systems (Damghanian, Zarei \& Kojuri, 2016; Ryu, Kim \& Kim 2018). As with all forms of online interactions, e-Filing carries a range of risks, the most prominent of these being related to privacy and performance (Bhuasiri et al., 2016; Ryu, Kim \& Kim 2018). Privacy can be threatened when the personal information revealed through tax returns is accessed and used for nefarious purposes (Ryu, Kim \& Kim 2018), and as such privacy and security are important. Performance risk can occur when using e-Filing. Performance risk refers to a situation wherein consumers fear that an online service will suddenly cease to function; i.e. the website will stop loading, or they will lose their internet connection, and their activities will be left incomplete (Damghanian, Zarei, \& Kojuri, 2016:220). If individuals perceive e-Filing as carrying high levels of personal and performance risk, they will be less likely to use the system when filing their tax returns. Conversely, when individuals perceive online services as less risky, they are more willing to use these services and enter their data. Against this premise, the following hypothesis is proposed:

H3: Perceived risk has a negative and significant impact on taxpayers' intention to use e-Filing.

\section{Perceived Risk as the Mediating Variable}

Perceived risk has been positioned in several studies as equal to perceived usefulness and perceived ease-of-use in determining users' intent to adopt a technology. However, subjective knowledge is a prerequisite for risk recognition (Yoon, Ro \& Cho, 2019), and this subjective knowledge can only be obtained through an understanding of the uses and benefits of technology and technology-based services (Dowling \& Staelin, 1994). As such, unlike previous studies, this study assumes that perceived risk mediates how the usefulness and ease-of-use of e-Filing are perceived. Generally, risk and usefulness have a positive correlation; high levels of risk are associated with high levels of usefulness, while low levels of risk are associated with low levels of usefulness (Slovic \& Peters, 2006). Perceived risk, as well as the uncertainty and disorder inherent to the online world, can pose a significant obstacle to the adoption of online services (Kim, Ferrin \& Rao, 2009). Individuals do not only evaluate risk rationally, but also emotionally, and such perceptions of risk contribute to their decision in using electronic services (Slovic \& Peters, 2006). Individuals recognize that privacy risks are inherent in their use of online services, they fear that the information they input to 
use online services may be leaked (Ryu, Kim \& Kim 2018). Consequently, although individuals understand that technology-based services can provide them with significant benefits, their decisions to use such services are also heavily informed by the potential risks that they perceive as inherent to these services.

The decision to adopt a technology is also informed by its perceived risk. As Ryu, Kim and Kim (2018) argue, individuals' willingness to use electronic media is influenced by various risks, and their perceptions of these risks influence how they perceive electronic services. This implies that, where users perceive technology-based services negatively, they are more likely to avoid using these services - even when they are easy to use. Thus, perceived risk is hypothesized as follows:

H4: Perceived risk mediates the impact of perceived usefulness on the intention to use e-Filing for income taxes.

H5: Perceived risk mediates the impact of perceived ease of use on the intention to use e-Filing for income taxes.

\section{Gender as the Moderating Variable}

Academics and practitioners have given attention to how gender affects the adoption and use of technology (Pengnate \& Sarathy, 2017; Leon, 2018). As found in several studies, gender influences how individuals perceive and use new technology (Theriault, Smale \& Haider, 2017; Obisesan, 2014). A study of Tanellari et al. (2014) demonstrates that gender does not only influence individuals' decision to use technology, but also how they use it. They also found that it shapes individuals' responses to and decision to adopt technology. Meanwhile, Leon (2018) - through a survey of university students (238 females, 387 males) in the United States - found that the adoption of cellular applications is influenced by information quality, self-efficacy, perceived ease-of-use, and perceived usefulness. All of these were partially moderated by gender; for example, perceived ease-of-use and perceived usefulness were both more important for women than for men. Furthermore, as argued by Venkatesh and Morris (2000), the cognitive structures of men and women are constructed differently, and as a result men and women use different decision-making processes regarding whether or not to adopt technology.

Several studies have emphasized the importance of considering the moderating effect of gender on the adoption of technologybased services and systems (i.e. Leon, 2018; Theriault, Smale \& Haider, 2017; Obisesan, 2014). However, within the context of e-services in Indonesia, the academic literature has only rarely discussed the moderating influence of gender on users' willingness to adopt technology; this factor, thus, requires careful consideration. The association between the latent constructs (perceived benefits and perceived ease-of use) and the endogenous construct (intention to adopt e-Filing) may be positively or negatively influenced by gender. As such, research should consider the moderating influence of gender on endogenous and exogenous constructs (Guo et al., 2018). In this study, gender has been identified as a moderating factor because individual users' gender influences their decision to use electronic services. Identifying factors that influence the willingness to use e-services will help the Indonesian government make gender-sensitive policies for promoting e-Filing adoption. More importantly, from a practical perspective, understanding the moderating influence of gender on Indonesians' willingness to use e-Filing will help decision-makers improve existing systems and promote the broader adoption of such services. This study will thus complement extant literature on technology adoption and gender. By understanding how women and men perceive the benefits and ease-of-use of e-Filing systems, the factors that promote and hinder their adoption can be identified and the future development of 


\section{Figure 1. Proposed Conceptual Model}

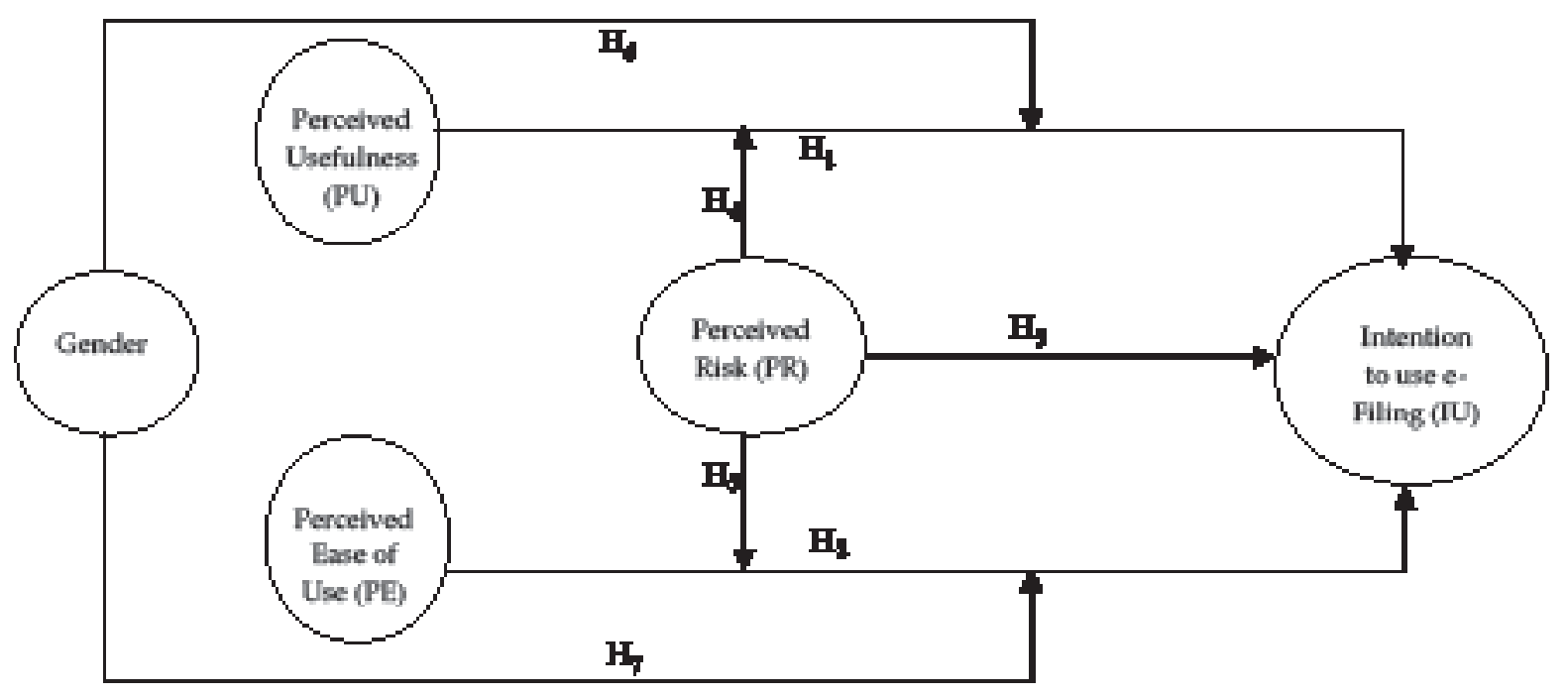

Source: Own elaboration based on existing literature.

these technologies can be guaranteed. Hence, the study further hypothesizes that:

H6: Gender moderates the impact of perceived usefulness on the intention to use e-Filing.

H7: Gender moderates the impact of perceived ease of use on the intention to use e-Filing.

\section{Methods}

\section{Design, Sample and Instruments}

This study employs a quantitative approach to understand the link between the variables measured through the research instruments (Creswell, 2014). It uses both primary and secondary data; primary data were collected through online questionnaires uploaded to https://docs.google.com as well as questionnaires distributed directly to respondents. These questions were used to collect demographic information as well as data on perceived usefulness, perceived ease of use, perceived risk, and intention to use. Secondary data were collected through secondary sources, including academic articles, publications, and other resources.

Participants of this study were Indonesian citizens who had previous experience with e-Filing systems. Although they originated from all parts of Indonesia, most participants came from the Jakarta Capital District. Following the rules of thumb recommended by Roscoe (1975), as quoted by Sekaran and Bougie (2017: 264), a multivariate research should involve between 30 and 500 respondents. In addition to this view, Hair et al., (2019) posit that a predictive structural model as being investigated in this study, requires neither a strong theoretical basis nor a large sample size; a small sample size is sufficient (Hair et al. 2019). Questionnaires were distributed to 231 respondents; 105 respondents completed their questionnaires through an online form, while 108 submitted their questionnaires through e-mail or mail. Questionnaires were completed over the course of three months, between April and June 2018; this period was chosen because it coincided with the filing of tax returns (ending in April 2018). Of the 231 completed questionnaires, 219 were valid for analysis. Convenience sampling was used, as there were no detailed or comprehensive lists of taxpayers who had already used e-Filing. In convenience sampling, only general criteria are used to filter participants. In this case, only one criterion was used: previous experience with e-Filing. To reach potential participants throughout Indonesia, the author 
used the most convenient approach. Links to an online questionnaire were sent by text message and email to individuals included in her address book and connected through her social networks (Facebook, LinkedIn, Google+). Questionnaires were also completed through direct interactions with colleagues and other members of the professional community. Pursuant to Machin et al. (2018), a pilot study involving thirty respondents was first conducted to test the clarity of the instrument and its language. Based on the feedback from these thirty respondents, sentences that were identified as unclear, ambiguous, or otherwise problematic were improved to ensure that the instrument could provide accurate and valid data. Data validity was ascertained through three approaches: (1) construct validity; (2) content validity; and (3) criterion validity. Construct validity is used to ascertain whether the method is appropriate for the construct. To be valid, the indicators in the questionnaire must be rooted in relevant knowledge, as measured through the acceptance model. This questionnaire contained items that were relevant to individuals' intention to accept e-Filing. Construct validity is measured through convergent validity and discriminant validity. Statistically, all instruments used this study have loading factors $>0.70$ and average extracted variance value of $>0.50$, which suggested good construct validity (Hair et al., 2019; Wong, 2016). Content validity is also used to determine whether the questionnaire covers all relevant aspects of the topic being investigated (Hair et al., 2014). Experts were generally consulted to determine the content validity of the measurement scale used in this study. In this study, technology acceptance has been included in the questionnaire as an indicator, then developed using relevant research and theories (Wong, 2016; Hair et al., 2014). Next, the criterion validity was ascertained through the first question in the questionnaire: "How many times you have used
e-Filing to file your taxes?" Criterion validity was thus determined, as it did not rely solely on respondents' self-reported statements.

Participants in the empirical study were asked to rate their level of perception on the measurement items reflecting perceived usefulness, perceived ease of use, perceived risk and their intention to use e-Filing. A five-point Likert scale, 1 = strongly disagree, $5=$ strongly agree), was employed to measure 20 items. The measurement instrument is derived from the TAM constructs validated by Davis (1989) as well as from previous research, as modified to reflect the goals of this study. To understand perceptions of usefulness, ease of use, risk, and user intent, this study borrows its items from Davis (1989). Items dealing specifically with perceived usefulness were also adapted from Camilleri (2018), while items dealing with perceived ease of use were incorporated from Camilleri (2018) and Zaidi, Henderson, and Gupta (2017). Finally, items measuring perceived risk were adapted from Kim, Ferrin, and Rao (2009), Lin et al. (2012), and Ryu, Kim, and Kim (2018).

\section{The Statistical Analysis}

This paper applies the partial least square approach to structural equation modeling (PLS-SEM). PLS-SEM is used predominantly to evaluate complex models that incorporate various constructs, variables, and structural channels, as data can be analyzed without assuming normal distribution (CepedaCarrion, Cegarra-Navarro, \& Cillo, 2019; Gunzler et al., 2013). It is used to predict endogenous latent variables and identify main variables through measurement (outer model) and structure (inner model), as well as by testing hypotheses (path coefficients) (Hair et al., 2019). Construct validity of the outer model is measured by testing convergent validity and discriminant validity, while construct reliability is analyzed by examining various constructs' composite reliability through their internal 
Figure 2. Importance-Performance Grid

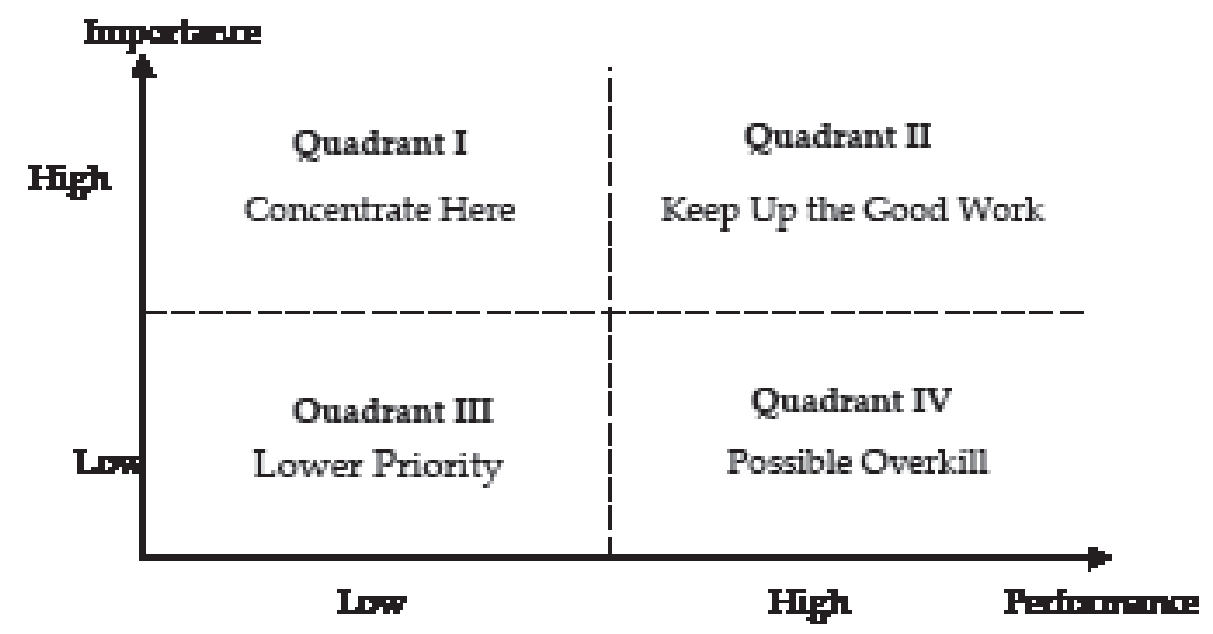

Source: Minta and Stephen (2017:537); Deng and Pierskalla (2018:16).

consistency and Cronbach's Alpha (Hair et al., 2019). In inner model analysis, hypotheses may be tested through bootstrapping and through the comparison of the t-tables and t-statistics of distinct constructs. Path analysis is subsequently used to determine the direct or indirect influence of latent constructs and variables. Assessment of the fitness of the model is undertaken by measuring the coefficient of the R-squared, and the Goodness-of-Fit (GOF) index (Hair et al., 2019; Hussaini et al., 2018; Wong, 2016; Henseler \& Sarstedt, 2013).

\section{Importance-Performance Matrix Analysis (IPMA)}

IPMA is a supplemental technique that enriches PLS-SEM analysis (Ringle \& Sarstedt, 2016). It examines performance and importance and can be used to position variables relative to each other within the model. In structural analysis, IPMA can offer important information that can improve efficiency of the analysis as it enables an interpretation of the constructs' effects (Bervell \& Umar, 2018; Ringle \& Sarstedt, 2016). According to Minta and Stephen (2017) as well as Deng and Pierskalla (2018), IPMA may be understood as a four-quadrant matrix (Q1-Q4). Each quadrant requires a different strategy to improve its targeted variable. Q1 is labelled high importance, low performance; as such, variables within this quadrant require managerial attention to improve their performance. Variables in Q2high importance, high performance-should be maintained. Q3 hosts variables that are of low importance and low performance, and as such require little attention or concern. Finally, Q4 contains those variables that are of low importance and high performance; this may indicate that resources are being squandered.

\section{Results \\ Measurement Model}

The participants' characteristics are shown in Table 1. Table 2 summarizes the results of construct reliability and construct convergent validity testing. Items were deemed reliable if loading factor > 0.70 (Carmines \& Zeller, 1979; Hair et al., 2014). All items required outer loadings of $>0.70$. As two indicators of PR (PR6 and PR7) had an outer loading $<0.7$, these indicators were deemed unsatisfactory and removed from the research model. Although PR8 had loading factors of 0.588 , it was not removed from analysis; the PR construct required a minimum average variance extracted value of 0.5 , this construct 
Table 1.

Characteristic of Respondents

\begin{tabular}{|c|c|c|c|}
\hline Particulars & Items & Frequency $(n=219)$ & Percentage \\
\hline \multirow[t]{2}{*}{ Gender } & Male & 121 & 55 \\
\hline & Female & 98 & 45 \\
\hline \multirow[t]{6}{*}{ Age (years) } & $20-25$ & 39 & 17.8 \\
\hline & $>25-30$ & 54 & 24.7 \\
\hline & $>30-35$ & 40 & 18.3 \\
\hline & $>35-40$ & 24 & 11.0 \\
\hline & $>40-45$ & 22 & 10.0 \\
\hline & $>45$ & 40 & 18.3 \\
\hline \multirow{3}{*}{$\begin{array}{l}\text { Current } \\
\text { employment }\end{array}$} & Businessmen & 19 & 8.7 \\
\hline & Private Company Employee & 126 & 57.5 \\
\hline & Government Employee & 74 & 33.8 \\
\hline \multirow{4}{*}{$\begin{array}{l}\text { Frequency } \\
\text { in using } \\
\text { e-Filing }\end{array}$} & 1 time & 42 & 19.2 \\
\hline & 2 times & 76 & 34.7 \\
\hline & 3 times & 53 & 24.2 \\
\hline & More than 3 times & 48 & 21.9 \\
\hline
\end{tabular}

Note: targeted respondents of this study are all e-Filing users in Indonesia. However, after the survey was conducted, respondents who participated only came from 18 provinces in Indonesia, namely: Bali, DKI Jakarta, Gorontalo, West Java, Central Java, East Java, West Kalimantan, South Kalimantan, Central Kalimantan, Lampung, NAD, NTB, Papua, South Sulawesi, North Sulawesi, West Sumatra, South Sumatra, North Sumatra. Around $69 \%$ of respondents are those from DKI Jakarta Province.

Source: Own calculation based on the primary data.

Table 2.

Assessment of the Measurement Model

\begin{tabular}{|c|c|c|c|c|c|}
\hline Constructs & Indicators & Loadings & Cronbach Alpha & AVE & $\mathrm{CR}$ \\
\hline \multirow{4}{*}{$\begin{array}{l}\text { Perceived usefulness } \\
\text { (PU) }\end{array}$} & PU1 & 0,866 & 0,800 & 0,870 & 0,870 \\
\hline & PU2 & 0,739 & & & \\
\hline & PU3 & 0,837 & & & \\
\hline & PU4 & 0,718 & & & \\
\hline \multirow{4}{*}{$\begin{array}{l}\text { Perceived ease of use } \\
\text { (PE) }\end{array}$} & PE1 & 0,75 & 0,777 & 0,852 & 0,852 \\
\hline & PE2 & 0,853 & & & \\
\hline & PE3 & 0,669 & & & \\
\hline & PE4 & 0,791 & & & \\
\hline \multirow{6}{*}{$\begin{array}{l}\text { Perceived risk } \\
\text { (PR) }\end{array}$} & PR1 & 0,808 & 0,848 & 0,883 & 0,883 \\
\hline & PR2 & 0,671 & & & \\
\hline & PR3 & 0,869 & & & \\
\hline & PR4 & 0,674 & & & \\
\hline & PR5 & 0,849 & & & \\
\hline & PR6 & 0,583 & & & \\
\hline \multirow{3}{*}{$\begin{array}{l}\text { Intention to use e-Filing } \\
\text { (IU) }\end{array}$} & IU1 & 0,874 & 0,884 & 0,925 & 0,925 \\
\hline & IU2 & 0,923 & & & \\
\hline & IU3 & 0,894 & & & \\
\hline
\end{tabular}

Source: Own calculation using SmartPLS. 
Table 3.

Discriminant Validity: Fornell and Lacker's Criterion

\begin{tabular}{cccccc}
\hline Variables & IU & PE & PR & PU & Discriminant Validity \\
\hline IU & $\mathbf{0 , 8 9 7}$ & & & & Valid \\
PE & 0,421 & $\mathbf{0 , 7 6 9}$ & & & Valid \\
PR & 0,538 & 0,343 & $\mathbf{0 , 7 5 0}$ & & Valid \\
PU & 0,608 & 0,678 & 0,509 & $\mathbf{0 , 7 9 3}$ & Valid \\
\hline
\end{tabular}

Source: Own calculation using SmartPLS.

Note: The diagonal is the value of AVE square root (in bold).

Table 4.

Collinearity Testing Results

\begin{tabular}{cccccc}
\hline Constructs & Tolerance Value & $\begin{array}{c}\text { Variance } \\
\text { Inflation Factor }\end{array}$ & Constructs & Tolerance Value & $\begin{array}{c}\text { Variance } \\
\text { Inflation Factor }\end{array}$ \\
\hline PU & $<5-10$ & 1,850 & PU & $<5-10$ & 2,209 \\
PE & $<5-10$ & 1,850 & PE & $<5-10$ & 1,874 \\
& & PR & 1,352 \\
\hline Dependent & & Dependent & \\
Variable is PR & & Variable is IU & \\
\hline
\end{tabular}

Source: Own calculation using SmartPLS.

was appropriate for more than $50 \%$ of variants (Hair et al., 2014; Ramayah et al., 2018). Table 2 shows that, after the above two indicators were removed, the outer loading value still did not meet reliability criteria; as such, Cronbach's Alpha and Composite Reliability value were used to determine that the latent variables were reliable. Validity testing showed that all the latent variables had an AVE value of greater than 0.5 , as such, the latent variables are highly valid.

In PLS-SEM analysis, it is necessary to conduct discriminant validity testing to ensure that the constructs are not correlated (Hair et al., 2019; Mohajan, 2017). Discriminant validity shows the distinctness and uniqueness of the construct. It can be measured through the AVE value, with a threshold value of 0.5 (Fornell \& Lacker, 1981).

\section{Variance Inflation Factor (VIF)}

To ensure that the analyzed model is free of collinearity issues, the Variance Inflation Factor (VIF) was examined; a VIF value between 5 and 10 indicates collinearity (Wong,
2016). It was found that the VIF value of the construct PU was $1.850, \mathrm{PE}=1.850$, with the dependent variable PR; while the VIF value of the construct PU was 2.209, PE $=1.874$ and PR $=1.352$, with the dependent variable IU. All VIF values were $<5$, and as such these variables were free of collinearity.

\section{Structural Model R-squared}

The $R$-squared $\left(\mathrm{R}^{2}\right)$ value shows the extent to which latent independent variables influence dependent variables (Hussain et al., 2018; Henseler \& Sarstedt, 2013). $\mathrm{R}^{2}$ value of 0.67 indicates substantial/good influence; a value of 0.33 indicates moderate influence; and a value of 0.19 indicates weak influence (Hussain et al., 2018). Table 5 shows that Perceived Risk (PR) had a $\mathrm{R}^{2}$ value of $0.259(<0.33)$, and as such had moderate influence, with PU and PE capable of explaining 25.9 percent of variations in PR; remaining variances can be explained by variables other than those analyzed. PU, PE, and PR had an influence of $0.449(<0.67)$ on IU 
Intention to Use (IU) e-Filing, and as such these variables have moderate influence. With an $\mathrm{R}^{2}$ value of $0.449, \mathrm{PU}, \mathrm{PE}$, and PR can explain $44.9 \%$ of variations of intention to use e-Filing. Several factors may contribute to this relatively weak $R^{2}$ value. First, the $\mathrm{R}^{2}$ value may be relatively weak owing to the context of the phenomenon being studied. In Structural Equation Modelling, the $\mathrm{R}^{2}$ value depends on the phenomenon being studied. If this phenomenon is relatively well understood, the goodness of fit will be high $\left(\mathrm{R}^{2}\right.$ $>0.7$ ). However, if this phenomenon has yet to be understood well, a lower $\mathrm{R}^{2}$ value may be accepted (Benitez et al., 2020: 12). Second, in studies that use cross-sectional data, the $\mathrm{R}^{2}$ value is generally low (ranging from 0.2-2.3) (Henseler et al., 2014: 188). Third, in studies that investigate individual behaviour, an $\mathrm{R}^{2}$ value of 0.20 may be considered high (Hair, Ringle, \& Sarstedt, 2011; Henseler, Ringle, \& Sinkovics, 2009). As this study investigates individuals' intention to use e-Filing, the R2 value of perceived risk (0.259) is relatively high.

Table 5.

Variance Explained

\begin{tabular}{lc}
\hline \multicolumn{1}{c}{ Variables } & $\mathbf{R}^{\mathbf{2}}$ \\
\hline Perceived Risk (PR) & 0,259 \\
Intention to use (IU) & 0,449 \\
\hline
\end{tabular}

Source: Own calculation using SmartPLS.

\section{The Goodness-of-Fit (GoF)}

GoF is used to validate the entirety of a statistical model by ascertaining how well it fits a set of observations (Henseler, 2018; Henseleer,
Ringle \& Sarsted, 2015). The GoF is particularly useful for a PLS multi-group analysis (PLSMGA) (Henseler, 2018). The formula to obtain the GoF value is GoF $=\sqrt{ }\left(A V E x R^{2}\right.$. A GoF value may fall into three categories: high $(>$ $0.36)$, moderate $(0.25-0.36)$, and low $(0.1-0.25)$ (Wong, 2016; Hair et al., 2019). The GoF value can be calculated by multiplying the root of average communalities index (AVE values) by the average $\mathrm{R}^{2}$. Table 6 shows that the GoF of the inner model is $0.479(>1)$. This suggests that PU, PE, PR, and gender all influence IU and have substantial predictive power (Hussain et al., 2018).

Table 6.

The Goodness of Fit Testing Results

\begin{tabular}{ccc}
\hline Constructs & AVE & $\mathbf{R}^{\mathbf{2}}$ \\
\hline PU & 0,628 & \\
PE & 0,591 & \\
PR & 0,562 & 0,259 \\
IU & 0,805 & 0,449 \\
Average Values & 0,647 & 0,354 \\
AVE $\times$ R $^{2}$ & 0,229 & \\
GOF = & $\mathbf{0 , 4 7 9}$ & \\
\hline
\end{tabular}

Source: Own calculation using SmartPLS.

The hypotheses were tested by evaluating the channel coefficient produced through bootstrapping. The t-statistics value was compared with the $t$-table value, with a level of confidence of $95 \%(\alpha=5 \%)$. Degree of freedom (d.f) $=n-k-1$; then d.f $=219-3=216$, t-table value is 1.645. The results of bootstrapping, shown in Table 7, indicate that PU's t-statistic value is greater than its t-table value (5.017>1.645). The positive path coefficient value $(0.432)$

Table 7.

Hypothesis Testing Results

\begin{tabular}{cccccl}
\hline Hypotheses & Path & $\boldsymbol{t}$-Values & $\boldsymbol{\rho}$-Values & Path Coefficient & \multicolumn{1}{c}{ Results } \\
\hline H1 & PU -> IU & 5,017 & 0,000 & 0,432 & Supported $^{*}$ \\
H2 & PE -> IU & 0,331 & 0,740 & 0,023 & Not Supported \\
H3 & PR -> IU & 4,810 & 0,000 & 0,307 & Supported $^{*}$ \\
\hline
\end{tabular}

${ }^{*} p<0.05$, one-tailed test.

Source: Own calculation using SmartPLS. 
Table 8.

Mediation Results

\begin{tabular}{cccccc}
\hline Hypotheses & Path & $t$-Values & $\rho$-Values & Path Coefficient & Results \\
\hline H4 & PU -> PR -> IU & 3,471 & 0,001 & 0,157 & Supported $^{*}$ \\
H5 & PE -> PR -> IU & 0,042 & 0,967 & 0,157 & Not supported $^{2}$ \\
\hline
\end{tabular}

${ }^{*} p<0.05$, one-tailed test.

Source: Own calculation using SmartPLS.

Table 9.

Result of Multi-group Analysis

\begin{tabular}{|c|c|c|c|c|c|c|c|c|}
\hline \multirow[b]{2}{*}{ Hypotheses } & \multirow[b]{2}{*}{ Path } & \multicolumn{2}{|c|}{ Standardized Beta } & \multicolumn{2}{|c|}{ t-Values } & \multicolumn{2}{|c|}{$p$-Values } & \multirow[b]{2}{*}{ Results } \\
\hline & & $\begin{array}{c}\text { Males } \\
(\mathrm{n}=121)\end{array}$ & $\begin{array}{c}\text { Females } \\
(\mathrm{n}=98)\end{array}$ & $\begin{array}{c}\text { Males } \\
(\mathrm{n}=121)\end{array}$ & $\begin{array}{c}\text { Females } \\
(\mathrm{n}=98)\end{array}$ & $\begin{array}{c}\text { Males } \\
(\mathrm{n}=121)\end{array}$ & $\begin{array}{c}\text { Females } \\
(\mathrm{n}=98)\end{array}$ & \\
\hline H6 & $\mathrm{PU} \rightarrow \mathrm{IU} \rightarrow \mathrm{GR}$ & 0,370 & 0,498 & $3,012^{*}$ & $4,445^{*}$ & 0,003 & 0,000 & Supported \\
\hline H7 & $\mathrm{PE} \rightarrow \mathrm{IU} \rightarrow \mathrm{GR}$ & 0,121 & $-0,062$ & 1,261 & 0,617 & 0,208 & 0,537 & Not supported \\
\hline
\end{tabular}

${ }^{*} p<0.05$, one-tailed test.

Source: Own calculation using SmartPLS.

indicates that PU has a positive influence on IU, supporting H1. In other words, PU has a positive influence of 0.432 on IU. PE, conversely, does not significantly affect IU, as the $t$-statistics value $<$ than the $t$-table value $(0.331<1.645)$; as such, $\mathrm{H} 2$ is rejected. Examining the influence of PR on IU, the t-statistics value was $4.810(<1.645)$, indicating that $\mathrm{H} 3$ is supported, PR's path coefficient on IU is 0.307 , further indicating a positive association between PR and IU.

\section{Mediation Analysis}

Referring to Wong (2016) and Meule (2019), the mediation effect was tested through two approaches. First, the significance of the direct effect was tested; if the direct effect was insignificant, then the hypothesized mediation effect does not exist. Testing was conducted through bootstrapping, without the mediator variable (Nitzl, Roldan, \& Ceped, 2016; Gorondutse and Hilman, 2016). Second, the indirect mediating effect was measured by including the mediator variable in its analysis (Wong, 2016). Table 7 shows a significant direct effect between variables, and from the $t$-values obtained it can be concluded that PU and PR have a significant direct effect on IU.
$\mathrm{PE}$, conversely, did not have a significant direct effect on IU, and as such it may be assumed to not play a mediating role. Mediation testing was conducted by including the mediator variable (PR) in the inner model. Table 8 shows the indirect effects between variables. From the available $t$-values, it may be concluded that PU has a significant indirect effect on IU, as mediated by PR, because the $t$-value is greater than the t-table $(3.471>1.645)$. This shows that PR has a statistically significant mediating effect on IU. As such, H4 is accepted. Table 8 below also shows that PR does not significantly mediate PE's influence on IU ( $\mathrm{t}$-value $<\mathrm{t}$-table).

\section{Moderation Analysis: Multi-Group Analysis}

Multi-group analysis shows that gender has a significant effect on IU $(3.012>1.645)$. The regression coefficient value of 0.370 shows that, in men, PU's influence on IU is positively moderated by gender. The $\mathrm{t}$-statistic value among women was $4.445>1.645$, indicating that gender significantly moderates the influence of PU on IU. The regression coefficient value was higher amongst women than amongst men (0.498 for men, and 0.370 for women). In other words, PU has a greater influence on IU among women than among men. Multi-group testing 


\section{Figure 3. Results of the Structural Model}

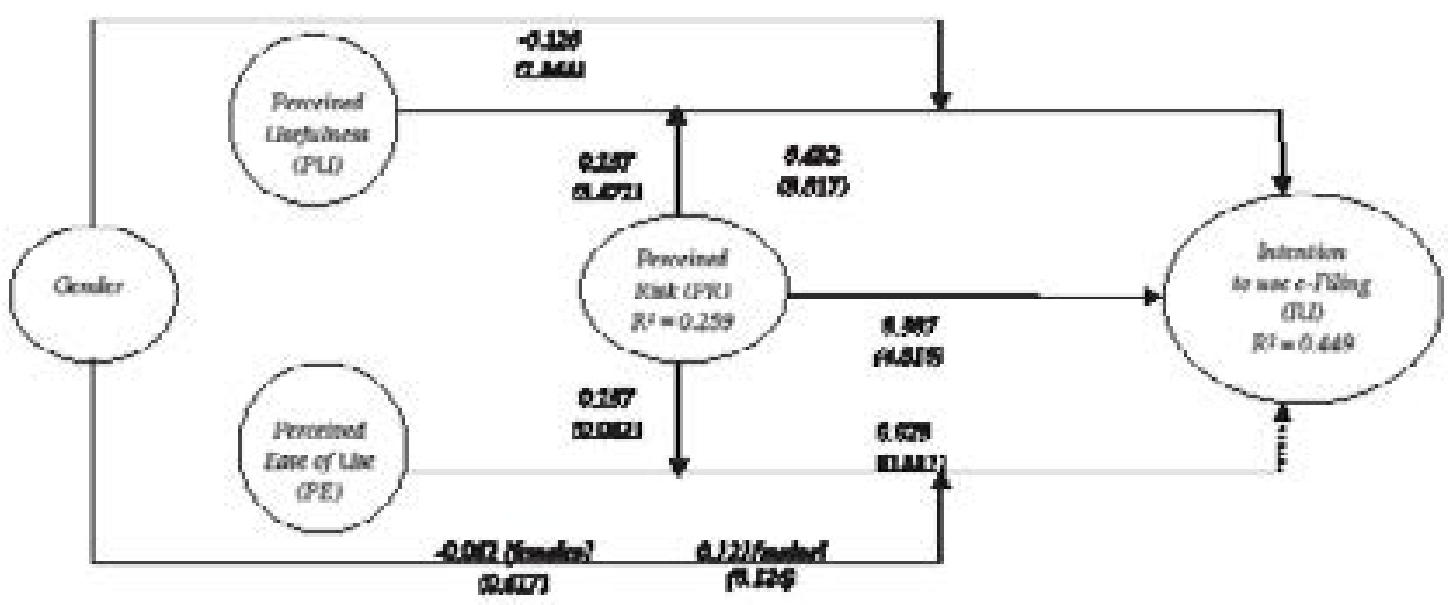

Note: $t$-statistics are in the parenthesis; the dotted lines indicate non-significant paths.

Source: Own calculation using SmartPLS.

also shows that gender does not moderate PE's influence on IU; as such, $\mathrm{H} 7$ is rejected.

\section{Importance-Performance Matrix Analysis (IPMA)}

Figure 4 and Table 10 show the results of IPMA of IU. IPMA categorizes two elements as low or high, following the procedures recommended by Chung and Yun (2014). Importance and performance may be categorized as high or low based on their position relative to their medians, thereby creating quadrants. If importance is positioned below the median, it is categorized as "low",

\section{Table 10.}

\section{Importance and Performance Matrix}

\section{Result}

\begin{tabular}{lcc}
\hline \multicolumn{1}{c}{ Items } & Importance & Performance \\
\hline $\begin{array}{l}\text { Perceived Usefulness of } \\
\text { e-Filing }\end{array}$ & 0,589 & 83,641 \\
$\begin{array}{l}\text { Perceived Ease of Use of } \\
\text { e-Filing }\end{array}$ & 0,022 & 77,924 \\
Perceived Risk of e-Filing & 0,307 & 74,083 \\
Gender & 0,021 & 55,251 \\
\hline
\end{tabular}

Note: the median is obtained from the mean index of importance and performance after being sorted from highest to lowest.

Source: Own calculation using SmartPLS. while if it is positioned above the median it is categorized as "high". In this study, the median for importance was set at 0.1645 , while the median for performance was set at 76.003. As such, gender and EU were categorized as low-importance, while PR and PU were categorized as high-importance. PU and PR are the variables that most strongly determine IU, as these variables are classified as "high performance" and "high importance".

\section{Discussion}

This study intended to ascertain the main factors that influence taxpayers' intent to use e-Filing to file their tax returns. The empirical results demonstrate that perceived usefulness and perceived risk strongly influence the intent to use e-Filing, with gender and perceived risks being moderator and mediator variables (respectively). Perceived usefulness significantly and positively determines the intent to use technology. These findings also coincide with those of previous TAM studies, which have consistently shown that perceived usefulness is a stronger predictor than ease of use (as seen in previous studies, such as Hubert et al., 2019; Camilleri, 2018; Venkatesh, et al., 2003; Davis, 1989). In other words, the 


\section{Figure 4. Importance and Performance of Intention to use e-Filing Result}

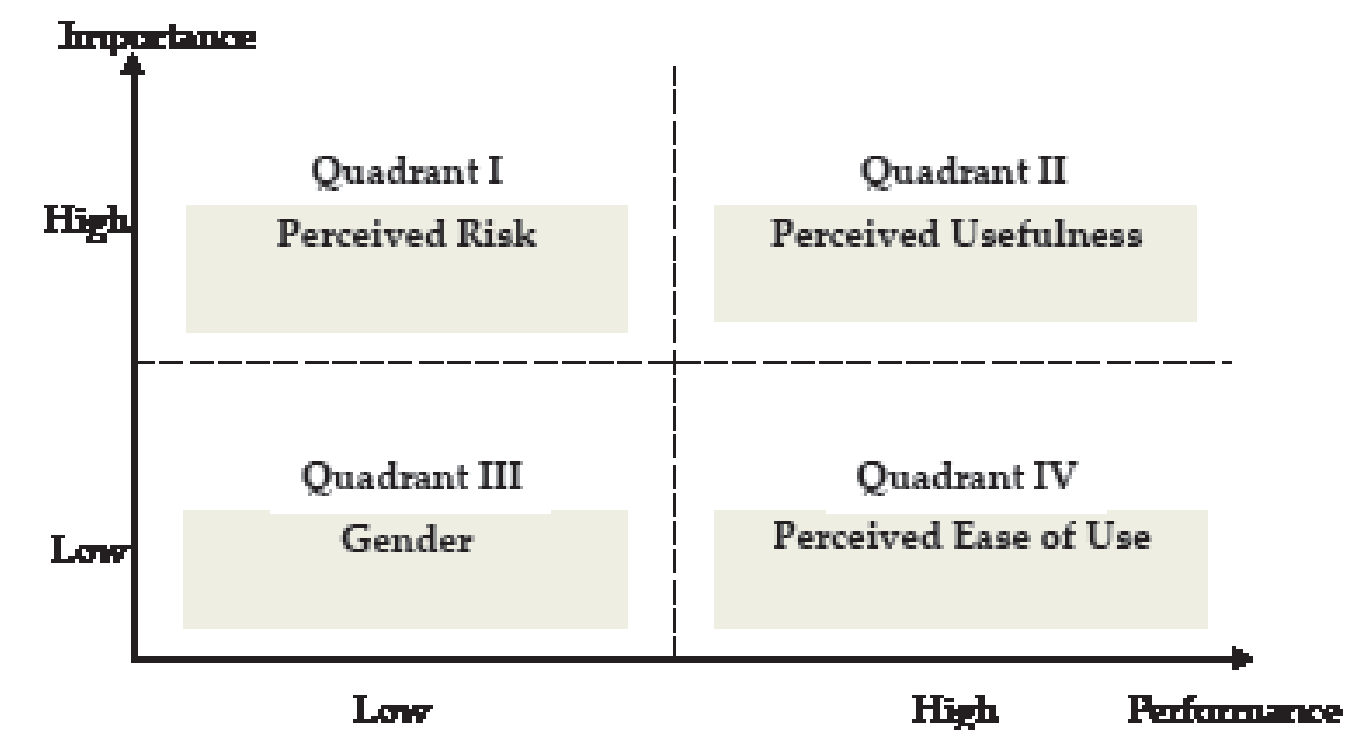

Source: Own calculation using SmartPLS.

perceived usefulness of e-Filing technology draws the interest of adopters, even if the technology itself is not easy to use. It may thus be surmised that the government institutions must continue to market the benefits and uses of e-Filing, particularly its cost-efficiency, effectiveness, and comfort. Surprisingly, and unlike in previous studies such as that by Jahongir and Shin (2014), Cho (2016), Zaidi, Henderson and Gupta (2017), perceived ease of use does not significantly influence users' willingness to adopt the technology.

Perceived risk, meanwhile, has a significant and a positive influence on the intent to use e-Filing. Nonetheless, this study has found that taxpayers are willing to use e-Filing even though they recognize that certain risks are inherent. This finding contradicts those of Charag, Fazili and Bashir (2019) and Bhuasiri et al. (2016), who found that perceived risk is negatively correlated with users' acceptance and use of electronic services. There was no negative correlation between perceived risk and willingness to use online services, as taxpayers have the knowledge to control and identify potential risks; they also recognize the importance of avoiding risky behavior when accessing online services (Gong et al., 2019). Furthermore, referring to the age distribution of respondents, the majority of respondents $(42.5 \%)$ were between the ages of 20 and 30 , and thus could be classified as millennials ${ }^{1}$ (Merriman, 2015). Millennials, commonly termed, were raised with computer and internet technology, and as such they understand and can mitigate the risks of internet usage. They also actively use smart phones for their online activities (Merriman, 2015). These factors help explain the finding that, although millennials recognize the risks inherent to e-Filing, these risks do not negatively affect their intention to use e-Filing.

Gender moderates the influence of perceived usefulness on the intention to use e-Filing. This finding supports those of Leon (2018) and Venkatesh and Morris (2000), who found that gender moderates the influence of perceived benefit on intention to adopt

\footnotetext{
1 This paper borrows from Merriam (2015): Young Millennials (age 17-24), Old Millennials (age 25-34), Gen X (age 35-50), and Baby Boomers (age 51-64).
} 
e-services. Perceived usefulness is positively correlated with intention to use among both men and women, but the influence is stronger among women $(49.8 \%)$ than men $(37 \%)$. This suggests that women tend to emphasize the usefulness of e-Filing when deciding to use it to file their tax returns. More importantly, unlike men, women tend to consider others' opinions when making decisions (Venkatesh \& Morris, 2000). All of these conditions influence how women perceive the usefulness of online services and allow them to obtain more information on available services.

\section{Conclusion}

This study shows that perceived usefulness and perceived risk positively determines the intention to use e-Filing. Perceived risk has a mediating effect while gender has a moderating effect on the intention to use e-Filing technology. Results from IPMA reveal that perceived usefulness and perceived ease of use of e-Filing are the variables that most strongly determine intention to use e-Filing. This study contributes to the broader discourse of TAM and the adoption of technology-based services. It has also contributed a significant understanding of how gender intersects with the perceived usefulness, ease of use, and risk of e-Filing in Indonesia.

This study has several recommendations that will help guide the development of e-Filing practices and policies in Indonesia. The Indonesian government has yet to entice taxpayers to use the e-Filing system. The e-Filing system would be more effectively adopted if the Indonesian government were to increase its efforts to market its e-Filing applications and websites, as well as ensure that the system is easy to access and use. This study has also shown that perceived usefulness contributes significantly to the intention to use e-Filing. As such, the government should further develop features and applications that increase taxpayers' awareness of the e-Filing system. By doing so, it could potentially find new adopters who are willing to use the system. Important to note is the influence of gender. Men and women are differently influenced by the perceived usefulness and ease of use of technology. Although both men and women are significantly influenced by perceived usefulness, the influence is stronger among women. Recognizing this, the government can primarily direct its policies and approaches at male taxpayers, enabling them to better understand the benefits of e-Filing.

Some significant results were found in this study, however, it has several shortcomings. This study has only considered how perceived usefulness, perceived ease of use, perceived risk, and gender influence the adoption of e-Filing in Indonesia. However, according to the literature, the intent to adopt technology is influenced by a range of factors. As such, subsequent studies should apply the latest conceptual models to understand the diverse factors that influence the decision to use technology. Furthermore, it is necessary to better understand the contribution of demographic factors. The findings of this current study cannot be generalized for all taxpayers, given that the majority of its respondents were between the ages of 25 and 30. Furthermore, this study was conducted only in Indonesia, and as such its findings may only apply to this specific territory. There may also have been biases in respondents' answers, particularly when completing the online questionnaires.

\section{Acknowledgment}

The author thanks the Department of Business Administration, Atma Jaya Catholic University for providing partial funding for this study.

\section{References}

Anouze, A. L., \& Alamro, A. S. (2019). Factors Affecting Intention to Use E-Banking in Jordan. International Journal of Bank 
Marketing, 1-27. doi:10.1108/IJBM-102018-0271

Bélanger, F., \& Carter, L. (2012). Digitizing Government Interactions with Constituents: An Historical Review of E-Government Research in Information Systems. Journal of the Association for Information Systems, 13(5), 363-394. doi:10.17705/1jais.00295

Benitez, J., Henseler, J., Castillo, A., \& Schuberth, F. (2020). How to Perform and Report an Impactful Analysis using Partial Least Squares: Guidelines for Confirmatory and Explanatory IS Research. Information $\mathcal{E}$ Management, 57(2), 1-16. Retrieved from https://doi.org/10.1016/j.im.2019.05.003

Bervell, B., \& Umar, I. N. (2018). Utilization Decision towards LMS for Blended Learning in Distance Education: Modeling The Effect of Personality Factors in Exclusivity. Knowledge Management $\mathcal{E}$ E-Learning: An International Journal, 10(3), 309-333. doi:10.34105/j.kmel.2018.10.018

Bhuasiri, W., Zo, H., Lee, H., \& Ciganek, A. P. (2016). User Acceptance of e-Government Services: Examining an e-Tax Filing and Payment System in Thailand. Information Technology for Development, 22(4), 672-695. doi:10.1080/02681102.2016.1173001

Camilleri, M. A. (2018). Understanding the Impact of Acceptance of Digital Media for Stakeholder Engagement. An Experimental Analysis. Journal of Small Business and Enterprise Development, 26(4), 504-521. doi:10.1108/JSBED-02-2018-0042

Carmines, E. G., \& Zeller, R. (1979). Reliability and Validity Assessment. Beverly Hills, CA: Sage Publications.

Cepeda-Carrion, G., Cegarra-Navarro, J.-G., \& Cillo, V. (2019). Tips to Use Partial Least Squares Structural Equation Modelling (PLS-SEM) in Knowledge Management. Journal of Knowledge Management, 23(1), 67-89. doi:10.1108/JKM-05-2018-0322

Charag, A. H., Fazili, A. I., \& Bashir, I. (2019). Determinants of Consumer's Readiness to
Adopt Islamic Banking in Kashmir. Journal of Islamic Marketing, 1-30. doi:10.1108/ JIMA-10-2018-0182

Chung, S.-H., \& Yun, D. (2014). Revising Importance-Performance Analysis Combined with Regression Model: Applied to Seniors' Travel Motivation and Performance Experiences. International Journal of Tourism Sciences, 14(2), 126-144. doi:10.1080/15980634.2014.11434694

Creswell, J. W. (2014). Research Design: Qualitative, Quantitative and Mixed Methods Approaches (4th ed.). Thousand Oaks, California: Sage.

Damghanian, H., Zarei, A., \& Kojuri, M. A. (2016). Impact of Perceived Security on Trust, Perceived Risk, and Acceptance of Online Banking in Iran. Journal of Internet Commerce, 15(3), 214-238. doi:10.1080/153 32861.2016.1191052

Davis, F. (1989). Perceived Usefulness, Perceived Ease of Use, and User Acceptance of Information Technology. MIS Quarterly, 13(3), 319-340. doi:10.2307/249008

Davis, F., Bagozzi, R., \& Warshaw, P. (1989). User Acceptance of Computer Technology: A Comparison of Two Theoritical Models. Management Science, 35(8), 982-1003. doi:10.1287/mnsc.35.8.982

Deng, J., \& Pierskalla, C. D. (2018). Linking Importance-Performance Analysis, Satisfaction, and Loyalty: A Study of Savannah, GA. Sustainability, 10(704), 1-17. doi:10.3390/su10030704

Dinu, A. M. (2012). Modern Methods of Risk Identification in Risk Management. International Journal of Academic Research in Economics and Management Sciences, 1(6), 67-71.

Dowling, G. R., \& Staelin, R. (1994). A Model of Perceived Risk and Intended RiskHandling Activity. Journal of Consumer Research, 21, 119-134. doi:10.1086/209386

Fornell, C., \& Larcker, D. (1981). Evaluating Structural Equation Models with 
Unobservable Variables and Measurement Error. J. Market. Res, 18(39), 39-50 . doi: $10.2307 / 3151312$

Gorondutse, A. H., \& Hilman, H. (2016). Mediation Effect of the Organizational Culture on the Relationship between Perceived Ethics on Performance of SMEs. Journal of Industrial Engineering and Management, 9(2), 505-529. doi:10.3926/ jiem.1892

Gunzler, D., Chen, T., Wu, P., \& Zhang, H. (2013). Introduction to Mediation Analysis with Structural Equation Modeling. Shanghai Arch Psychiatry, 25(6), 390-394. doi:10.3969/j.issn.1002-0829.2013.06.009

Hair, J. F., Hult, G. T., Ringle, C., \& Sarstedt, M. (2017). A Primer on Partial Least Squares Structural Equation Modeling (PLS-SEM) (2nd ed.). Thousand Oaks, California: Sage.

Hair, J. F., Hult, G., Ringle, C., \& Sarsted, M. (2014). A Primer on Partial Least Squares Structural Equations Modeling (PLS-SEM). Los Angeles: SAGE.

Hair, J. F., Ringle, C. M., \& Sarstedt, M. (2011). PLS-SEM: Indeed a Silver Bullet. Journal of Marketing Theory and Practice, 19(2), 139152. doi:10.2753/MTP1069-6679190202

Hair, J. F., Ringle, C. M., \& Sarstedt, M. (2019). The Use of Partial Least Square Path Modeling in International Marketing. Journal of Marketing Theory and Practice, 19(2), 277-320.

Hair, J. F., Risher, J. J., Sarstedt, M., \& Ringle, C. M. (2019). When to Use and How to Report the Results of PLS-SEM. European Business Review, 31(1), 2-24. doi:10.1108/ EBR-11-2018-0203

Henseler, J. (2018). Partial Least Squares Path Modeling: Quo Vadis? Qual Quant, 52, 1-8. doi:10.1007/s11135-018-0689-6

Henseler, J., \& Sarstedt, M. (2013). Goodnessof-fit indices for partial least squarespath modeling. Comput Stat, 23, 565-580. doi:10.1007/s00180-012-0317-1
Henseler, J., Ringle, C., \& Sarsted, M. (2015). A New Criterion for Assessing Discriminant Validity in Variance-based Structural Equation Modeling. J. Acad. Mark. Sci, 43, 115-135. doi:10.1007/s11747-014-0403-8

Hubert, M., Blut, M., Brock, C., Zhang, R. W., Koch, V., \& Riedl, R. (2019). The Influence of Acceptance and Adoption Drivers on Smart Home Usage. European Journal of Marketing, 53(6), 1073-1098. doi:10.1108/ EJM-12-2016-0794

Hussain, S., Fangwei, Z., Siddiqi, A. F., Ali, Z., \& Shabbir, M. S. (2018). Structural Equation Model for Evaluating Factors Affecting Quality of Social Infrastructure Projects. Sustainability, 10(1415), 1-25. doi:10.3390/ su10051415

Kim, D., Ferrin, D., \& Rao, H. (2009). Trust and Satisfaction, Two Stepping Stones for Successful E-Commerce Relationship: A Longitudinal Exploration. Information Systems Research (INFORMS), 20(2), 237257. doi:10.1287/isre.1080.0188

Leon, S. (2018). Service Mobile Apps: A Millennial Generation Perspective. Industrial Management \& Data Systems, 118(9), 1837-1860. doi:10.1108/IMDS-102017-0479

Machin, D., Campbell, M. J., Tan, S. B., \& Tan, S. H. (2018). Sample Size for Clinical, Laboratory and Epidemiology Studies (4th ed.). Hoboken, New Jersey: John Wiley and Sons.

Merriman, M. (2015). What if The Next Big Disruptor Isn't a What but a Who? Retrieved June 12, 2017, from ey.com: http:// www.ey.com/Publication/vwLUAssets/ EY-rise-of-gen-znew-challengeforretailers/\$FILE/EY-rise-of-gen-znewchallenge-for-retailers.pdf

Meule, A. (2019). Contemporary Understanding of Mediation Testing. Meta-Psychology, 3, 1-7. doi:10.15626/MP.2018.870

Minta, N. K., \& Stephen, O. (2017). ImportancePerformance Matrix Analysis (IPMA) of 
Service Quality and Customer Satisfaction in the Ghanaian Banking Industry. International Journal of Academic Research in Business and Social Sciences, 7(7), 532550. doi:10.6007/IJARBSS/v7-i7/3120

Mohajan, H. K. (2017). Two Criteria for Good Measurements in Research: Validity and Reliability. Annals of Spiru Haret University Economic Series, 17(3), 58-82. Retrieved from https://www.ceeol.com/search/ article-detail?id $=673569$

Mortimer, G., Hasan, S. F., Andrews, L., \& Martin, J. (2016). Online Grocery Shopping: The Impact of Shopping Frequency on Perceived Risk. The International Review of Retail, Distribution and Consumer Research, 26(2), 202-223. doi:10.1080/09593969.2015 .1130737

Nitzl, C., Roldan, J. L., \& Ceped, G. (2016). Mediation analysis in partial least squares path modeling", Industrial Management \& Data Systems. Industrial Management $\mathcal{E}$ Data Systems, 116(9), 1849-1864. doi:10.1108/IMDS-07-2015-0302

Obisesan, A. (2014, August 15). Gender Differences in Technology Adoption and Welfare Impact among Nigerian Farming Households. Retrieved August 12, 2018, from Munich Personal RePEc Archive: https://mpra.ub.uni-muenchen.de/58920/

Pantow, A. K., Sutrisno, \& Saraswati, E. (2016). Taxpayer Behavior Analysis of Using E-Filing as a Tax Reporting System (Empirical Study in Malang City). Imperial Journal of Interdisciplinary Research, 2(4), 717-721.

Pengnate, S., \& Sarathy, R. (2017). An Experimental Investigation of The Influence of Website Emotional Design Features on Trust in Unfamiliar Online. Computers in Human Behavior, 67(C), 49-60. doi:10.1016/i.chb.2016.10.018

PWC. (2018). PWC Survey: Digital Banking in Indonesia 2018. Retrieved July 20, 2019, from https://www.pwc.com/id/ en/publications/assets/financialservices/ digital-banking-survey-2018-pwcid.pdf Ramayah, T., Cheah, J., Chuah, F., Ting, H., \& Memon, M. A. (2018). Partial Least Squares Structural Equation Modelling (PLS-SEM) Using SMARTPLS 3.0: An Update and Practical Guide to Statistical Analysis (2nd ed.). Malaysia: Pearson.

Rana, N. P., Dwivedi, Y. K., Lal, B., Williams, M. D., \& Clement, M. (2017). Citizens' adoption of an electronic government system: towards a unified view. Information Systems Frontiers, 19(3), 549568. doi:10.1007/s10796-015-9613-y

Ringle, C. M., \& Sarstedt, M. (2016). Gain More Insight from Your PLS-SEM Results: The Importance-Performance Map Analysis. Industrial Management \& Data Systems, 116(9), 1865-1886. doi:10.1108/IMDS-102015-0449

Ritchey, F. (2008). The Statistical Imagination: Elementary Statistics for the Social Sciences (2 ed.). New York, USA: McGrawHill.

Ryu, Y., Kim, S., \& Kim, S. (2018). Does Trust Matter? Analyzing The Impact of Trust on The Perceived Risk and Acceptance of Nuclear Power Energy. Sustainability, 10(758), 1-17. doi:10.3390/su10030758

Schaupp, L. C., Carter, L., \& McBride, M. E. (2010). E-file Adoption: A study of U.S. Taxpayers' Iintentions. Computers in Human Behavior, 26(4), 636-644. doi:10.1016/j.chb.2009.12.017

Sekaran, U., \& Bougie, R. (2017). Research Method for Business: A Skill-Building Approach (7 ed.). United Kingdom: John Wiley \& Sons Ltd.

Singh, S., \& Srivastava, R. (2018). Predicting The Intention to Use Mobile Banking in India. International Journal of Bank Marketing, 36(2), 357-378. doi:10.1108/IJBM-12-2016-0186

Slovic, P., \& Peters, E. (2006). Risk Perception and Affect. Current Directions Psychological Science, 15, 322-325. doi:10.1111/j.14678721.2006.00461.x 
Tanellari, E., Kostandini, Wabbi, G., Bonabana, Jackline, \& Murray, A. (2014). Gender Impacts on Adoption of New Technologies: The Case of Improved Groundnut Varieties in Uganda. African Journal of Agriculture and Resource Economics, 9(4), 300-308. doi:10.22004/ag.econ.197017

Theriault, V., Smale, M., \& Haider, H. (2017). How Does Gender Affect Sustainable Intensification of Cereal Production in The West African Sahel? Evidence from Burkina Faso. World Development, 92, 177191. doi:10.1016/j.worlddev.2016.12.003

Venkatesh, V., \& Morris, M. G. (2000, March). Why Don't Men Ever Stop to Ask for Directions? Gender, Social Influence, and Their Role in Technology Acceptance and Usage Behavior. MIS Quarterly, 24(1), 115139. doi:10.2307/3250981

Venkatesh, V., Morris, M., Davis, G., \& Davis, F. (2003). User Acceptance of Information Technology: Towards a Unified View. MIS Quaterly Management Information System, 27(3), 425-478. doi:10.2307/30036540

Widiyanesti, S., \& Reynaldi, M. R. (2017). Analisis Minta Penggunaan Layanan E-Filing oleh Wajib Pajak melalui Pendekatan Technology Acceptance
Model(TAM) di KPP Pratama Purwakarta. Jurnal Manajemen Indonesia, 16(1), 63-70. doi:10.25124/jmi.v16i1.730

Wong, K. K.-K. (2016). Technical Note: Mediation Analysis, Categorical Moderation Analysis, and Higher-order Constructs Modeling in Partial Least Squares Structural Equation Modeling (PLS-SEM): A B2B Example Using SmartPLS. The Marketing Bulletin, 26, 1-23. doi:10.13140/RG.2.1.1643.0562

Yoon, W., Ro, Y. S., \& Cho, S.-i. (2019). Mediation Analysis of the Effect of Practical Training on the Relationship between Demographic Factors, and Bystanders' Self-efficacy in CPR Performance. PLoS ONE, 14(4), 1-14. doi:10.1371/journal.pone.0215432

Zahid, H., \& Din, B. H. (2019). Determinants of Intention to Adopt E-Government Services in Pakistan: An Imperative for Sustainable Development. Resources, 8(128), 1-25. doi:10.3390/resources8030128

Zaidi, S. K., Henderson, C. D., \& Gupta, G. (2017). The Moderating Effect of Culture on E-filing Taxes: Evidence from India. Journal of Accounting in Emerging Economies, 7(1), 134-152. doi:10.1108/ JAEE-05-2015-0038 